TEGAR 4 (1) (2020) 29-34
Journal of Teaching Physical Education in Elementary School
Available online at :
https://ejournal.upi.edu/index.php/tegar/article/view/26708
DOI: https://doi.org/10.17509/tegar.v4i1.26708

\title{
The Effect of Training Method and Educability on Karate-Kata Skill
}

\section{Siti Aisyah ${ }^{1,2}$, Tatang Muhtar ${ }^{1}$, Yunyun Yudiana ${ }^{1}$}

${ }^{1}$ Komite Olahraga Nasional Indonesia (KONI) Jawa Barat, Indonesia

${ }^{2}$ Program Studi Pendidikan Olahraga, Sekolah Pascasarjana, Universitas Pendidikan Indonesia, Indonesia

\begin{tabular}{|c|c|}
\hline Article Info & Abstract \\
\hline $\begin{array}{l}\text { Article History: } \\
\text { Received : August } 2020 \\
\text { Accepted : September } 2020 \\
\text { Available Online : October } 2020 \\
\text { Keywords: } \\
\text { karate--kata skill, motor educability, } \\
\text { whole part whole training method. }\end{array}$ & $\begin{array}{l}\text { This study was aimed at examining the effect of whole part hole training method and } \\
\text { whole training method on the karate-kata skill of the students with high motor educa- } \\
\text { bility and low motor educability who joined Karate extracurricular. The method used } \\
\text { was the ex post facto method with factorial design } 2 \times 2 \text {. The samples of the study } \\
\text { were } 80 \text { elementary school students joining Karate extracurricular in SDIT Darul } \\
\text { Ma'arif, Bandung Districts. The training was conducted twice a week for } 20 \text { weeks. } \\
\text { The test instrument used was the karate-kata Heian Shodan test instrument. The ob- } \\
\text { tained data were analyzed by MS Excel } 2010 \text { software with two-way Anova test. The } \\
\text { results of the study show that: the whole part whole training method has a better im- } \\
\text { pact on the karate-kata skill than the whole training method; the karate-kata skill of } \\
\text { the high motor educability group was better than the low motor educability group; } \\
\text { there was no interaction between the training method and motor educability on the } \\
\text { mastery of karate-kata skill. According to the result of the study, it concludes that the } \\
\text { whole part whole training method is more effective that the whole training method, } \\
\text { while a high motor educability is better than the low motor educability. }\end{array}$ \\
\hline
\end{tabular}




\section{INTRODUCTION}

The guidance and development of sports in primary schools carried out by the Ministry of Education and Culture is one of the four pillars of the national education development policy, which includes spiritual reinforcement, feelings management, mind work, and sports. Sports are physical activities that can arouse enthusiasm, foster sportsmanship, friendship, and brotherhood. Sports can also have a strategic meaning for nation and character building or national character development (Kemendikbud, 2020). Conceptually, child development is based on three domains, namely psychomotor, cognitive and affective. The psychomotor domain consists of physical and motor abilities based on biological (growth) and motor (functional) processes (Budi, Kusuma, Syafei, \& Stephani, 2019). This is inseparable from motor learning, which includes a wide range of phenomena, from relatively low mechanisms for maintaining movement calibration, to making high-level cognitive decisions about how to act in new situations (Krakauer, Hadjiosif, Xu, Wong, \& Haith, 2019).

Physical education programs are an important element of the school curriculum; being healthy is the path to every child's total growth and development (Pangrazi \& Beighle, 2019). One of the goals of physical education is to develop movement skills. With the development of various physical characteristics and maturity, individuals will develop skills to form movement skills, as well as skills for conducting various kinds of games and sports. The functions of physical education include increasing the harmony of nerves and muscle function, developing locomotor, non-locomotor, manipulative skills as well as accuracy, rhythm, power, reaction speed, and agility (Mahardika, 2016). Primary school age is around 7 to 11-year-olds, and this period is the development stage to see progress in cognitive, affective, and psychomotor aspects. Sports activities are in psychomotor domain. The development of sports at the elementary school level has progressed very rapidly in various kinds along with the existence of the National Elementary School Student Sports Olympiad (O2SN SD) or now called the National Elementary School Student Sports Competition (KOSN-SD). Almost every school organizes extracurricular sports clubs to compete at KOSN SD, especially in Kids'Athletics, Gymnastics, Swimming, Badminton, Pencak Silat, Karate, Mini Football.

KOSN-SD is very valuable and the right momentum for children to excel and compete fairly.
Besides, these activities can also provide a good learning experience, especially in teamwork, sportsmanship, self-acknowledgment, respecting opponents, and establishing the values of fair play (honest, friendly, respectful, and responsible) in every sporting event at KOSN-SD (The Directorate of Primary School, The Directorate General of Primary and Secondary Education, Ministry of Education and Culture, 2020). The presence of KOSN-SD attracts children's interest to participate in sports that are competed in KOSN. With the support of parents, children are motivated to participate in sports to get easier entry to the next level of education as in the Regulation of Minister of Education and Culture.

Karate is included in the sports that are competed in KOSN-SD, so many elementary school students have started practicing karate. Some schools set karate as an extracurricular activity. The opportunity to become athletes from an early age and the achievements in continuous championships of KOSN build the excitement in the students to practice and fight to become champions from the subdistrict level, city/regency, provincial, to the national level, and even to the international level. The achievement impacts the children's psychological development; therefore, it is necessary to prepare them with sports activities that they are interested in from an early age.

Karate is a relatively safe sport for children and adolescents when taught properly (Zetaruk, Violan, Zurakowski, \& Micheli, 2000). Karate is a martial art developed in the Ryukyu Islands (Japan) from the original fighting methods and Chinese kenpo. Karate is a martial art that can be practiced using the hands and feet to throw and block attacks (Emad et al., 2020). Karate training consists of two components: "Kumitè" which is characterized by sparring and fighting with partners and aims to avoid disqualification, and "Kata", characterized by different forms and sequences of movements such as battles against imaginary antagonists (Alesi et al., 2019). In karate competition, both kumite (sparring) and kata (form, a sequence of movements representing various attacks and defensive postures) are the two categories commonly competed. Its simplicity and comprehensiveness are the reasons why karate can be considered an attractive and crowd-friendly sport. Participants can join kata and kumite competitions either as individuals or as part of a team. It is not obligatory to enroll in both categories during the competition (Augustovicova, Dusana Cierna, 2018). 
Karate-Kata consists of a predetermined series of movements performed at explosive speed against an imaginary opponent, whereas kumite involves non-contact combat. The word 'kata' means 'form '; it combines techniques from various martial arts, and the athletes move in several directions (Doria et al., 2009). Kata is an artistic part of karate that requires motor control, rhythm and a capacity for movement differentiation. In national and international competitions, kata is judged based on specific parameters: technique, rhythm, strength, expressive movement and kime, namely the force produced by isometric contractions at the end of each technique (Scurati, 2008). Kata is a series of basic techniques (kihon) that are designed and performed in a determined order of attack and defense techniques and movements as a martial art possessed by different karate schools, namely Goju, Shito, Shotokan and Wado. Karate-Ka (karate practitioner) must have a good kihon to master kata in order to meet the competition scoring criteria. A number of physical components should be trained to present good and correct kata in order to master Karate-kata. Thus, the training given to a karate-ka must refer to the assessment rules of the World Karate Federation (WKF).

Mastering the karate-kata technique takes a relatively long time. Undergoing targeted and planned training and applying the correct and proper training principles can improve someone's ability to master karate-kata. Thus, the application of training methods becomes essential. According to (Pate, MacClenaghan, \& Rotella, 1984), "The training method is a means of forming skills, training as participation, and training aimed at increasing physical functional capacity and endurance". This opinion is supported by Harsono (1988), "Exercise is a systematic process of practicing or working, repeatedly conducted, with the increasing number of training or work loads." It can be said that the repetitive karatekata exercises and the increasing training load will improve the mastery of kata-karate skills faster, and automation of the kata movements will occur.

Skills are influenced by internal factors in the aspect of physical movement experience. Children who go through a period of multilateral development properly will quickly adapt to new motor skills, known as motor educability. Motor educability is a person's ability to learn new motor skills. The quality of motor educability provides an overview of a person's ability to learn new movements easily. The higher the motor educaability, the easier it will be to master new movements. Specific motor skills are essential for success in many sports. Conditioned reflexes are acquired through unique movement training based on basic motor skills customized for competition (Ma \& Qu, 2017).

When applying the training method, the trainers or coach should pay attention to the difference in the level of motor aducability in student trainees in order to achieve the goal of karate-kata skills practice. In addition to motor educability, the ability of kata skills mastery also depends on the cognitive skills of students in understanding and applying what the coach asks to, given the complex movements contained in karate-kata and the training process that has been followed also determines the mastery of karate-kata. Physical exercise is directed deliberately based on each individual's motor experience (Bakayev \& Bolotin, 2017). To train motor skills, an effective and efficient continuous training process is required. An athlete should be committed to following all phases, from the easiest training to the complex training stages, to achieve maximum results in the form of the best performance. A high skill level is only possible to acquire with continuous practices involving all the learning experiences gained (Kane, Mishra, \& Dutta, 2016).

In the training process in elementary school, the application of training methods is very important to make the best use of training sessions. The training method is a means of forming skills, participatory training, and training aimed at increasing physical functional capacity and exercise endurance. The principles of exercise strongly influence the training method in sports training. Hopefully, the students will be able to follow and master the karate-kata skills well and quickly by applying the training principles.

Based on the above explanation, this study aims to: 1) identify the distinction of karate-kata skills between the whole-part-whole training method and the whole-training method. 2) figure out the interaction between exercise methods and motor educability on karate-kata skills. 3) determine the difference in Karate-Kata skills between the wholepart-whole training method and the whole training method on the students who have high motor educability. 4) identify the difference in Karate-Kata skills between the whole-part-whole training method and the whole training method for students who have low motor educability. 


\section{METHOD}

The population in this study were 116 students of SDIT Darul Ma'arif who took extracurricular karate. Eighty students of SDIT Darul Ma'arif were taken as the research sample with the sampling technique using purposive sampling. This study used the ex-post-facto method, which was conducted after the event was happened (Widarto, 2013). Further, this study used a $2 \times 2$ factorial design (Fraenkel \& Wallen, 2009. P.277).

The instruments applied to measure karate-kata skills were kihon, gohon, and Heian shodan kata. To see the progress of twice-a-week trainings conducted by the students for twenty weeks, the preparation for kyu test was carried out with the whole-part-whole method and the whole training method. Karate-kata skills were tested with a competition approach referring to the demands of karate-kata techniques and performance according to the assessment of WKF regulations (World Karate Federation, 2019). The assessment is carried out by a competent and national certified referee.

\section{RESULTS AND DISCUSSION}

In this study, the measuring instrument used was the heian shodan karate-kata skill test. The heian shodan karate-kata skill assessment was carried out by an Inkanas referee certified as a West Java regional referee with the highest score of 6.50 and the lowest score of 2.97. The description of the data analysis results of the karate-kata skills test on students of SDIT Darul Ma'arif Bandung Regency was presented in table 1 .

Table 2. The factorial design of the effect of training methods and motor educability on karate-kata skill

\begin{tabular}{|c|c|c|c|}
\hline Motor Educability & \multicolumn{2}{|c|}{ Training Method } & \multirow[b]{2}{*}{ Mean } \\
\hline (B) & $\begin{array}{l}\text { Whole Part } \\
\text { Whole (A1) }\end{array}$ & $\begin{array}{l}\text { Whole } \\
\text { (A2) }\end{array}$ & \\
\hline High (B1) & 6.17 & 5.1 & 5.64 \\
\hline Low (B2) & 4.25 & 3.43 & 3.84 \\
\hline Mean & 5.21 & 4.27 & \\
\hline
\end{tabular}

From table 2, it can be concluded that the whole part whole training method is better applied than the whole training method, both for students who have high motor educability and low motor educability. Besides, the students who have high motor ability are better than those who have low motor ability in both training methods. Based on the hypothesis test analysis, the training methods applied to students significantly affect karate-kata skills. Likewise, motor educability has a significant effect on karate-kata skills.

Based on the hypothesis test results, there is a significant difference in a karate-ka's karate-kata skills trained with the whole-part-whole training method and those who were trained with the whole

Table 1. The recapitulation of karate-kata skill score calculation

\begin{tabular}{lllllllll}
\hline \multirow{2}{*}{ Statistics } & \multicolumn{1}{l}{ Training Method and Motor Educability } \\
\cline { 2 - 9 } & $\begin{array}{l}\text { ML } \\
\text { WPW }\end{array}$ & ML W & $\begin{array}{l}\text { ME } \\
\text { High }\end{array}$ & $\begin{array}{l}\text { ME } \\
\text { Low }\end{array}$ & $\begin{array}{l}\text { ML WPW } \\
\text { +MET }\end{array}$ & $\begin{array}{l}\text { ML WPW } \\
\text { +MER }\end{array}$ & $\begin{array}{l}\text { ML W } \\
\text { +MET }\end{array}$ & $\begin{array}{l}\text { ML W } \\
\text { +MER }\end{array}$ \\
\hline Mean & 5.10 & 4.28 & 5.61 & 3.80 & 6.17 & 4.25 & 5.20 & 3.43 \\
Median & 5.15 & 4.25 & 5.58 & 3.83 & 6.03 & 4.23 & 5.33 & 3.67 \\
Modus & 5.67 & 5.00 & 5.67 & 3.97 & 5.67 & 3.94 & 5.00 & 3.67 \\
Deviation & 1.04 & 0.92 & 0.31 & 0.25 & 0.27 & 0.25 & 0.24 & 0.27 \\
Standard & & & & & & & \\
Varians & 0.99 & 0.88 & 0.54 & 0.49 & 0.08 & 0.07 & 0.07 & 0.08 \\
Max Score & 6.50 & 5.50 & 6.50 & 4.63 & 6.50 & 4.63 & 5.50 & 3.83 \\
Min Score & 3.83 & 2.97 & 4.67 & 2.97 & 5.67 & 3.83 & 4.67 & 2.97 \\
Range & 2.67 & 2.53 & 1.83 & 1.66 & 0.83 & 0.80 & 0.83 & 0.86 \\
\hline
\end{tabular}

ML WPW $=$ Whole Part Whole Training Method

ML W= Whole Training Method

MET $=$ High Motor Educability

$\mathrm{MER}=$ Low Motor Educability 
training method. In karate-ka trained with the whole -part-whole training method, the mastery of karatekata skills is better than those who are trained with the whole training method at SDIT Darul Ma'arif. Karate-kas trained with the whole-part-whole training method got a total score of 205.73, more significant than the karate-kas trained with the wholetraining method at 175.33. This finding indicates that the whole part whole training method is better for the mastery of karate-kata skill.

The hypothesis testing results show that there is no interaction between the training methods and motor educability on karate-kata skill because the probability value is greater than the significance level at $\alpha=0.05$ with the interaction value $0.78292>$ 0.05 . Based on these findings, and supported by the results of previous research in several sports, it turns out that there is no interaction between training methods and motor educability on karate-kata skills.

Students with high motor educability who are trained with the whole-part-whole training method get a score of 121.20, and those with the same high motor educability who are trained with the whole training method get a score of 104.70. It shows that students who have high motor educability who are trained with the whole-part-whole training method are better than those trained with the whole training method in karate-kata skills. However, the whole training method supports students who have high motor ability to practice karate-kata skill drill to prepare for the karate-kata competition.

Students with low motor educability who are trained with the whole-part-whole training method get a score of 84.53 , while those trained with the whole training method get a score of 70.63. It shows that students who have low motor educability are better trained with the whole-part-whole training method. Students who have low motor educability are better trained with the whole-part-whole training method to improve their karate-kata skills. The complexity of karate-kata movements is strongly influenced by the students' movement skills of early age in which their attention span is low at the time of practice.

\section{CONCLUSION}

Based on data processing and data analysis, it can be concluded that there are differences in karatekata skills between the students who are trained with the whole-part-whole training method and those with the whole training method. The students who are trained with the whole-part-whole training meth- od do better than students trained with the wholepart training method in performing karate-kata skills. The karate-kata skills training results for students who have high motor educability are better than those with low motor educability. Because young students have low attention spans, the whole exercise method tends to be applied only by memorizing movement patterns without following the correct movement form. Karate-kata skills are required to meet certain assessment criteria, so implementing the whole-part-whole training will help students with low motor educability master karate-kata skills gradually to meet better assessment criteria. Further, the study results report that there is no interaction between the training methods and motor educability on karate-kata skills.

For further suggestions to the coach or trainers, the whole-part-whole training method can be applied in improving karate-kata skill, while the whole training method can be applied for competition preparation by considering the level of students' motor educability. Both training methods can be applied to the students who have high motor educability to complement each other; improving karatekata skills, and prepare for competitions. Meanwhile, the students who have low motor educability learn better and more effectively with the whole-part -whole training method.

\section{REFERENCE}

Alesi, M., Bianco, A., Padulo, J., Vella, F. P., Petrucci, M., Paoli, A., ... Pepi, A. (2019). Motor and cognitive development: the role of karate. Muscle Ligaments and Tendons Journal. https://doi.org/10.32098/ mltj.02.2014.04

Augustovicova, Dusana Cierna, J. A. (2018). Toplevel karate: analysis of frequency and successfulness of katas in K1 Premiere League. 18(4), 46-53. https:// doi.org/10.14589/ido.18.4.6

Bakayev, V., \& Bolotin, A. (2017). Pedagogical model of children swimming training with the use of method of substitution of hydrogenous locomotion. Proceedings of Faculty of Kinesiology, University of Zagreb (8th International Scientific Conference on Kinesiology), 763.

Budi, D. R., Kusuma, M. N. H., Syafei, M., \& Stephani, M. R. (2019). The Analysis of Fundamental Movement Skill in Primary School Student in Mountain Range. 11(Icsshpe 
2018), 195-198. https://doi.org/10.2991/ icsshpe-18.2019.56

Doria, C., Veicsteinas, A., Limonta, E., Maggioni, M. A., Aschieri, P., Eusebi, F., ... Pietrangelo, T. (2009). Energetics of karate (kata and kumite techniques) in top-level athletes. European Journal of Applied Physiology. https://doi.org/10.1007/s00421-009-1154-y

Emad, B., Atef, O., Shams, Y., El-Kerdany, A., Shorim, N., Nabil, A., \& Atia, A. (2020). IKarate: Improving Karate Kata. Procedia Computer Science, 170(2019), 466-473. https://doi.org/10.1016/j.procs.2020.03.090

Fraenkel, J. R., \& Wallen, N. E. (2009). Methodology glossary. How to Design and Evaluate Research in Education.

Kane, S. N., Mishra, A., \& Dutta, A. K. (2016). The Correlation between Butterfly Swimming Technique with Motor Ability and Motor Educability. Journal of Physics: Conference Series, 755(1). https://doi.org/10.1088/17426596/755/1/011001

Kemendikbud, D. dasar\&Menengah. (2020). Kompetisi olahraga siswa nasional.

Krakauer, J. W., Hadjiosif, A. M., Xu, J., Wong, A. L., \& Haith, A. M. (2019). Motor learning. Comprehensive Physiology. https:// doi.org/10.1002/cphy.c170043.

Ma, A. W. W., \& Qu, L. H. (2017). Effects of Karate Training on Basic Motor Abilities of Primary School Children. Advances in Physical Education. https://doi.org/10.4236/ ape.2017.72012.

Mahardika, D. B. (2016). Pengaruh Metode Pembelajaran Latihan dan Motor Educability Terhadap Keterampilan Dribel Bola Basket. Jurnal Pendidikan Unsika.

Pangrazi, R. P., \& Beighle, A. (2019). Dynamic physical education for elementary school children. Human Kinetics Publishers.

Pate, R. R., MacClenaghan, B. A., \& Rotella, R. J. (1984). Scientific foundations of coaching. Saunders College Publishing.

Scurati, P. L. I. S. L. R. (2008). Analysis of heart rate and lactate concentrations during coordinative tasks: pilot study in karate kata world champions. 41-46. https:// doi.org/10.1007/s11332-008-0053-7

Widarto. (2013). Penelitian Ex-Post Facto. Disampaikan pada kgiatan Pelatihan Metodologi Penelitian Pendidikan di Fakultas Teknik, Universitas Negeri Yogjakarta tang- gal, 27.

World Karate Federation. (2019). Karate Competition Rules Contents. Wkf Rules 2019, 1.1.2019, 90 .

Zetaruk, M. N., Violan, M. A., Zurakowski, D., \& Micheli, L. J. (2000). Karate injuries in children and adolescents. Accident Analysis and Prevention, 32(3), 421-425. https:// doi.org/10.1016/S0001-4575(99)00120-7 